IBIMA Publishing

Journal of Accounting and Auditing: Research \& Practice

http://www.ibimapublishing.com/journals/JAARP/jaarp.html

Vol. 2014 (2014), Article ID 338813, 8 pages

DOI: $10.5171 / 2014.338813$

Research Article

\title{
Lavelle Nursing Home: Family Run and Owned*
}

\author{
Alexander K. Buchholz \\ Department of Accounting, Brooklyn College of the City University of New York, Brooklyn, U.S.A \\ Correspondence should be addressed to: Alexander K. Buchholz; abuchholz@brooklyn.cuny.edu \\ Received date: 6 August 2013; Accepted date: 15 August 2014; Published date: 5 December 2014 \\ Academic Editor: Epameinondas Katsikas \\ Copyright @ 2014. Alexander K. Buchholz. Distributed under Creative Commons CC-BY 3.0

\begin{abstract}
While concluding the 2012 audit for Lavelle Nursing Home ("Lavelle"), the audit engagement team became aware of a recently signed severance agreement with one of the former shareholders, who was also one of the five cousins who established the business. The agreement provided for the possibility of payments ranging from $\$ 0-\$ 500,000$ for a period of ten years. Based on additional auditing procedures performed by the engagement team, it was discovered that the controller had not established any provision on the general ledger for this agreement. The controller also indicated that she was not going to record any provision. The audit engagement team brainstormed as to various alternatives to be taken and also needed to consult with the quality control department.
\end{abstract}

Keywords: Related party transactions, audit opinions, scope limitation, audit evidence

\section{Introduction}

Lavelle Nursing Home was established in 1980 as a two hundred and fifty bed skilled nursing facility. Unlike most nursing homes in the area, Lavelle was established as a forprofit C-Corporation healthcare entity, with five cousins each owning $20 \%$. Each cousin had previously worked in the healthcare field, and felt that they could add more quality of life to residents admitted to their facility while still maintaining an effective cost benefit relationship. Lavelle experienced several years of growth and prosperity until 2009, when the state reimbursement system took a turn for the worse, which resulted in the figures shown below.

Cite this Article as: Alexander K. Buchholz (2014), " Lavelle Nursing Home: Family Run and Owned ", Journal of Accounting and Auditing: Research \& Practice, Vol. 2014 (2014), Article ID 338813, DOI: 10.5171/2014. 338813 
Table 1: Partial Statement of Financial Position and Income Statement

\begin{tabular}{|c|c|c|c|c|c|c|}
\hline Year & $\mathbf{2 0 0 7}$ & $\mathbf{2 0 0 8}$ & $\mathbf{2 0 0 9}$ & $\mathbf{2 0 1 0}$ & $\mathbf{2 0 1 1}$ & $\begin{array}{c}\mathbf{2 0 1 2} \\
\text { (unaudited) }\end{array}$ \\
\hline $\begin{array}{c}\text { Net } \\
\text { income } \\
\text { (loss) }\end{array}$ & $\$ 1,000,000$ & $\$ 350,000$ & $\$(300,000)$ & $\$(500,000)$ & $\$(1,300,000)$ & $\$(732,000)$ \\
\hline $\begin{array}{c}\text { Retained } \\
\text { earnings }\end{array}$ & $5,000,000$ & $5,350,000$ & $5,050,000$ & $4,550,000$ & $3,250,000$ & $2,518,000$ \\
\hline
\end{tabular}

In addition, Lavelle received notification in 2011 that rates previously issued were in error by approximately $\$ 5 /$ day. Multiplying this adjustment in rates by resident census days resulted in a further reduction to net income and a corresponding liability of $\$ 520,000$ (which was recorded as part of due to third-party payors). By the end of 2011, the five cousins were becoming concerned as to whether they would be able to continue operating in an ever-changing healthcare environment. One cousin in particular had even considered to sell his interest to his other cousins and leave the business. The cousins were also concerned as to the increasing amount of current liabilities compared to current assets, as shown in Table 2.

Table 2: Current Assets and Current Liabilities

\begin{tabular}{|c|c|c|c|c|c|c|}
\hline Year & 2007 & 2008 & 2009 & 2010 & 2011 & $\begin{array}{c}2012 \\
\text { (unaudited) }\end{array}$ \\
\hline Current Assets (1) & $\begin{array}{c}\$ 3,000,00 \\
0\end{array}$ & $\$ 4,000,000$ & $\begin{array}{c}\$ 6,000,00 \\
0\end{array}$ & $\begin{array}{c}\$ 8,000,00 \\
0\end{array}$ & $\$ 8,500,000$ & $\$ 7,700,000$ \\
\hline $\begin{array}{l}\text { Current Liabilities } \\
\text { (2) }\end{array}$ & $3,000,000$ & $3,500,000$ & $4,000,000$ & $7,000,000$ & $7,750,000$ & $7,600,000$ \\
\hline
\end{tabular}

(1) Includes cash, accounts receivables, inventories and prepaid expenses

(2) Includes accounts payable, accrued payroll, current portion of long-term debt as well as current portion of due to third-party payors as a result of revenue rate changes

\section{Lavelle Audit}

The audit for the year ended December 31, 2012 had commenced late in the year due to turnover in management, particularly the addition of a new controller and junior accountant. The engagement fee had been negotiated at $\$ 85,000$. Although there was turnover in management, the audit had been progressing at a normal pace with little complications. Subsequent to year-end, management decided that it would try to obtain a bank loan to assist in expanding operations and develop an assisted living facility. Therefore, the conclusion of the audit as well as the signed independent auditors' unmodified report and audited financial statements were needed in order to secure the loan.

Audit fieldwork had been completed and the audit engagement team had returned to the office to finalize some work papers and ensure the draft financial statements were proceeding through quality control review. It was then on a Thursday afternoon, one day before the final report was to be signed, that the tax partner on the engagement paid a

Alexander K. Buchholz (2014), Journal of Accounting and Auditing: Research \& Practice,

DOI: $10.5171 / 2014.338813$ 
visit to the audit engagement partner. He informed the audit engagement partner that the fifth cousin was said to have left Lavelle January 1, 2012 and a severance agreement had only recently been formalized. The audit engagement team was not aware of this and realized that this severance agreement needed to be read prior to issuance of the financial statements. The audit senior manager contacted the controller who sent the signed agreement. Of particular note and concern was the below:

Lavelle agrees, except as otherwise provided for herein to pay, the sum of five hundred thousand $(\$ 500,000)$ dollars per year for a period of ten (10) years commencing January 1, 2013 and ending December 31, 2023 or upon death, if earlier (the "Term"), payable on a weekly basis. This represents payments for prior services rendered to Lavelle. Lavelle reserves the right to prepay the entire amount of the retirement payments to be paid during the Term. Such amount of prepayment shall be discounted based upon the then Applicable Federal Rate ("AFR").

Notwithstanding the foregoing, in the event the net income of Lavelle decreases due to increased general operating costs or loss of income during the Severance Term, the Board of Directors of Lavelle, in its sole discretion, has the right to reduce the amount of severance payment to be paid during the next calendar year on a proportionate basis provided. However, such reduction is for that next calendar year only and will not increase any subsequent.

The first part of the agreement now led the engagement team to believe that an accrual needed to be recorded. However, the second stipulation in the agreement raised some additional questions as to the exact amount of a liability to be recorded.

\section{Conversation with Controller}

The audit engagement partner had now been made aware of the situation and felt that a conversation was needed with Lavelle to understand and determine the underlying nature of the transaction. Lavelle's controller took the position that there should be no liability recorded based on point two. Point two indicated that, if in any given one year there are substantial losses; Lavelle would have no obligation to pay the cousin. Obviously, this would not be an issue. However, given the fact that this is a close family and this cousin has no other source of income, it was difficult for the audit partner, tax partner and senior audit manager to accept that there should be no provision established. The engagement team suggested that the liability be recorded in its entirety and discounted to account for the relevant time value of money. In addition, for each year in which the cousin is compensated less than $\$ 500,000$, an adjustment would be made and the excess would be picked up as revenue for that year. The controller believed that Lavelle would pay something, but that it would be difficult to determine at this time given the fact that they were not sure of future health care reimbursement. Furthermore, the recording of this liability would cause retained earnings and total stockholders' equity to fall into a deficit situation since the adjustment would be for $\$ 3,860,867 \quad(\$ 500,000 \times$ Present Value Factor-Ordinary Annuity (10 years, 5\% interest rate)). This would then not permit Lavelle to obtain a loan. The audit partner said that he would now have to get the quality control department involved to get their thoughts. The audit engagement partner, tax partner, and senior audit manager already knew that the quality control department would require something to be recorded (based on weighted average expectations for future earnings of the company) or possibly require modifications to be made to the independent auditors' report.

\section{Conversation with Quality Control}

The quality control department, after being brought up to speed and shown the agreement, concurred with the audit engagement team's conclusion that Lavelle 
needs to have some provision established. The team then indicated that it would be difficult for the client to determine overall net income (loss) for the next ten years. The quality control partner then suggested that Lavelle should be able to give a weighted probability of some sorts as they are going to give something to this cousin unless this is now giving rise to a possible going concern situation. The most straight-forward conclusion would be to record the discounted provision as of December 31, 2012. However, the engagement team knew that there were several possible questions as well as other matters which needed to be considered in order to present some options to Lavelle.

\section{Assuming Lavelle does not wish to record anything, should and how can the Independent Auditors' Report be modified?}

This question needed to be analyzed in two parts:

a. Should the Independent Auditors' Report be modified?

b. If so, how should it be modified?

This agreement carries with it the possibility of accruing a material liability. If the auditors were to propose that Lavelle record the entry, the following journal entry would be made on its general ledger:

\begin{tabular}{|l|c|c|}
\hline & Dr. & Cr. \\
\hline $\begin{array}{l}\text { Compensation } \\
\text { Expense }\end{array}$ & $\$ 3,860,867$ & \\
\hline $\begin{array}{l}\text { Severance } \\
\text { Liability }\end{array}$ & & $\$ 3,860,867$ \\
\hline
\end{tabular}

$<$ To record the agreement between Lavelle and the retiring cousin (partner) $>$

However, Lavelle's management explicitly indicated it did not wish to record this liability, since Lavelle has the right to reduce this $\$ 500,000$ yearly payment if the net income is not substantial enough to warrant incurring an additional expense. While it would be easiest on the audit engagement team to have this agreement voided, Lavelle does not seem to view this as an option. Therefore, in light of the above, the answer is the Independent Auditors' Report should be modified. Given the facts and circumstances, the choices available to the audit engagement partner are:

\section{a. Disclaimer of opinion AU-C Section 705.10 states:}

The auditor should disclaim an opinion when the auditor is unable to obtain sufficient appropriate audit evidence on which to base the opinion, and the auditor concludes that the possible effects on the financial statements of undetected misstatements, if any, could be both material and pervasive.

Based on the facts as described above, the audit engagement partner could decide to issue a disclaimer of opinion. This could be supported by the fact that the audit team has not been presented with any audit evidence to support either the accrual of the severance package or the non-accrual. Under auditing standards generally accepted in the United States of America (U.S. GAAS), the auditor must have sufficient appropriate audit evidence upon which to form the basis of an opinion. In this case, Lavelle seems to be rather hesitant to provide any evidence as they have taken the position that the net income is a variable which can't be determined and, therefore, does not allow for a proper provision of the severance accrual to be made. 


\section{b. Adverse opinion.}

AU-C Section 705.09 states that "the auditor should express an adverse opinion when the auditor, having obtained sufficient appropriate audit evidence, concludes that misstatements, individually or in the aggregate, are both material and pervasive to the financial statements."

Based on the facts as described above, the audit engagement partner could decide to issue an adverse opinion. The basis for this decision would be that the financial statements, if issued as currently presented, are materially misleading by the failure to record the liability of. Materiality is defined under AU-C Section 320.02 as follows:

- Misstatements, including omissions, are considered to be material if they, individually or in the aggregate, could reasonably be expected to influence the economic decisions of users made on the basis of the financial statements.

- Judgments about materiality are made in light of surrounding circumstances and are affected by the size or nature of a misstatement, or a combination of both.

- Judgments about matters that are material to users of the financial statements are based on a consideration of the common financial information needs of users as a group. The possible effect of misstatements on specific individual users, whose needs may vary widely, is not considered.

The entry to record a loss contingency would be as follows:

\begin{tabular}{|l|l|l|}
\hline & Dr. & Cr. \\
\hline Expense & $\mathrm{XXX}$ & \\
\hline Liability & & $\mathrm{XXX}$ \\
\hline
\end{tabular}

It would be appropriate to say that an individual would be materially misled as to the financial viability of Lavelle without the inclusion of the severance accrual, thus supporting issuing an adverse opinion.

Lavelle believes that it is probable but cannot reasonably estimate an amount to be recorded. What authoritative literature can the audit firm use in deciding this matter?

FASB Accounting Standards Codification (ASC) 275 focuses on the concept of loss contingencies. Loss contingencies in accounting are usually recorded as opposed to gain contingencies depending upon whether certain criteria are met. Typically, a loss contingency should be recorded if the two criteria stated below are met:

a. "Information available prior to the issuance of the financial statements indicates that it is probable that a liability has been incurred at the date of the financial statements.

b. The amount of the loss can be reasonably estimated" (Kieso, 2012). 
The controller indicated that they are probable that an amount will be recorded in future years in connection with the severance agreement. However, the controller is not sure that an amount can reasonably be estimated. Therefore, based on the criteria above, Lavelle is not able to record anything due to the uncertainty surrounding the amounts. However, FASB ASC 275 does contain a provision that, if the amount is probable and has a range of outcomes, the range should be disclosed. Therefore, the audit engagement partner might be able to suggest to the controller that, while an accrual need not be made at this time, a footnote should appear in the notes to the financials. This transaction should be footnoted as to the agreement made and the possible range of outcomes, which in this case ranges from $\$ 0-\$ 500,000$ for the next ten years along with the fact that this is a related party transaction. Additionally, the auditors may wish to add an emphasis of matter paragraph to the independent auditors' unmodified report calling special attention to this transaction.

If an entry does need to be recorded, tax implications need to be considered. What would be the nature of this transaction and how would it be handled?

If an amount needs to be recorded for this severance agreement, an additional expense would be recorded under accounting principles generally accepted in the United States of America (U.S. GAAP) along with a liability. This would result in a further reduction of net income on an accrual basis in accordance with U.S. GAAP. However, the income tax implications must also be considered. The Internal Revenue Code (IRC) would not allow any accrued severance liability to be deducted until the amount has been paid. Therefore, assuming Lavelle was to record the $\$ 3,860,867$ as a liability, there would exist a temporary difference between financial income and taxable as shown in Table 3 below:

Table 3: Computation of taxable loss

\begin{tabular}{|l|l|}
\hline & 2012 (Unaudited) \\
\hline Pretax financial loss $(1)$ & $(\$ 4,592,867.00)$ \\
\hline Temporary tax difference $(2)$ & $\$ 3,860,867.00$ \\
\hline Taxable loss & $(\$ 732,000.00)$ \\
\hline
\end{tabular}

1. Inclusive of the provision relating to the severance accrual.

2. This would be considered a Deferred Tax Asset. A "deferred tax asset represents the increase in taxes refundable (or saved) in future years as a result of deductible temporary differences existing at the end of the current year (Kieso, 2012)." Eventually, as Lavelle begins to pay out the severance amounts in future years, there will be a deductible amount shown on the corporate tax return. This will cause taxable income to be lower than pretax financial income.

Based on the above, the audit engagement partner would now be faced with another question. A Deferred Tax Asset is presented as an asset on the statement of financial position. However, the audit engagement partner would now have to consider if Lavelle should be establishing a valuation allowance. A valuation allowance should be established if "it is more likely than not that it will not realize some portion or all of the deferred tax asset" (Kieso, 2012) with more likely than not being more than fifty percent. This is an area where the audit and tax

Alexander K. Buchholz (2014), Journal of Accounting and Auditing: Research \& Practice,

DOI: $10.5171 / 2014.338813$ 
partners would need to prove that the full amount of the Deferred Tax Asset is realizable and that a valuation allowance either be established or not established. This would be proved by obtaining Lavelle's financial projections over the next several years.

Lavelle's position was that there was no guarantee the cousin would be paid anything if there were recurring losses. The quality control partner raised concerns that this may be indicative of a going concern. What evidence should the audit engagement team obtain to alleviate this concern?

A going concern is the assumption that an entity is expected to be in existence for a period of at least one year from the balance sheet date. Given the fact that Lavelle is anticipating losses as a result of the ever changing healthcare environment, this could be indicative of a possible going concern. Therefore, it is important that the audit engagement team obtain sufficient appropriate evidence to support the conclusion that Lavelle will be around one year from 2012. Lavelle's management should present to the audit engagement team the following information along with support for any numbers derived and any assumptions being used:

a. Operating budgets for several years,

b. Internal financial statements,

c. Cash flow projections,

d. Contracts with any major insurance companies which may bring additional revenue to Lavelle,

e. Any plans that Lavelle may have to bring in additional revenue or reduce expenses (i.e. Lavelle mentioned the establishment of an assisted living facility).
Should the audit engagement team recommend that the cousins attempt to void the agreement with the fifth cousin?

The audit engagement team is there to guide Lavelle to a solution which will be mutually beneficial while remaining within the guidelines of both U.S. GAAP and U.S. GAAS. The audit engagement team should inform Lavelle that, by voiding the agreement, the argument to record the liability would be removed and the independent auditors' report would be unmodified subject to no modifications. Obviously, this would be the easiest solution available.

\section{Second Conversation With Controller}

After having considered the questions above, the audit engagement partner, tax partner, and senior audit manager placed a second call to Lavelle. As Lavelle wanted to conclude the audit and send the signed financial statements and independent auditors' report to the bank, Lavelle was now taken aback by this follow-up conversation. The controller firmly believed that a provision could not be determined as there was no basis for recognition. The four other cousins were also on the call and firmly agreed with the controller's position. After going back and forth for three hours, one cousin suggested that the agreement simply be voided so that "this situation would go away"! Upon having heard this statement, there was total silence at that point by both parties. The question now was what the next course of action would be.

\section{Conclusion}

At the conclusion of the case, the four cousins were able to somehow persuade the fifth cousin to void his agreement. The recession of this agreement was sent to the audit engagement team who then submitted it to the quality control partner. After having read the voided agreement, the consensus was that there was no need for any accrual or footnote disclosure relating to the agreement. However, a related party 
footnote was added which merely disclosed that a former owner did retire and received a payout during the year. This position was documented with a memo and placed in the audit workpapers for future reference. The fifth cousin was subsequently hired, however, to be a part-time consultant and provide services on a fee for service basis. This was considered to be a related-party transaction, for which U.S. GAAP requires a footnote disclosure coupled with the related expense.

As stated before, this case study was based on real events. It was interesting to have been a part of and represents a unique circumstance of how far clients are sometimes willing to go to obtain the unmodified auditors' opinion. While some of the facts and names have been changed, this was the final outcome of the audit.

\section{References}

1. American Institute of Certified Public Accountants. "Modifications to the Opinion in the Independent Auditor's Report," Clarified Statement on Auditing Standards AU-C 705. (AICPA 2012).

2. American Institute of Certified Public Accountants. "Materiality in Planning and Performing an Audit," Clarified Statement on Auditing Standards AU-C 320. (AICPA 2012).

3. Kieso, Donald and Weygandt. (2012) Intermediate Accounting. Wiley.

* This case is based on real events. The names have been changed as well as some of the facts. 